\title{
Recent Divorce Trends and Patterns in Finland
}

\section{JARL LINDGREN}

Research Associate

The Population Research Institute

\section{Introduction}

Development towards an industrialized society, signifying drastic changes within the demographic sphere, began rather late in Finland. The demographic transition did not reach the masses prior to the turn of the century. The most extensive period came much later. As a whole, the transition has been shorter than in many other European countries but, on the other hand, it has been more rapid. Fertility, which started to decline in the first decade of the 20th century, sank in the 1970 s to one of the lowest in Europe. In 195040 percent of the population still made their living from agriculture, but by 1980 the corresponding proportion had declined to nine percent. Migration from rural to urban areas was intensive and urbanization rapid, implying expanding modernization with growing individualism, changes in the role of women, the collapse of family-kinship dominance, etc.

Even if in Finland trends in attitudes and behavior similar to those in the other European countries can be noticed, they mostly reach Finland with some time lag. Her northern position on the outer fringe of Europe obviously contributes to this. Further, the recentness of the transition from an agricultural society might be reflected in the fact that new trends do not extend as far as in neighboring countries to the west.

In Finland as in many other European countries the divorce rate started to increase in the mid-1960s. After a small peak at the end of the 1940 s caused by marriages contracted during the war, the crude divorce rate remained more or less unchanged until the end of the 1950s. Growth was rather modest in the 1960 s, but it rose rapidly in the beginning of the 1970 s. For a rather long time now the crude divorce rate has remained stable at a good two divorces per 1000 inhabitants and year (Figure 1).

F i g u r e 1. The crude divorce rate 1946-1982.

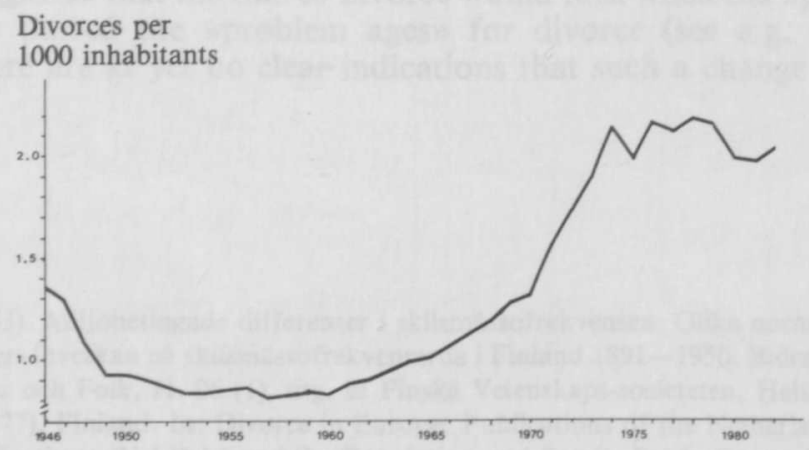

Source: Statistical Yearbook of Finland, 1954-1984 


\section{The causes behind the new divorce trends}

Principally the changes in the divorce rate could be considered the result of alterations in the demographic and societal structure.

The demographic structure is to a great extent determined by the age structure, but not by it alone. It also could be considered to include the occupation of spouses, their educational level and income. Farmers are often mentioned among occupations with a low divorce rate. Occupations with a high divorce rate are seen to include artists, among others. However, education, occupation and income are mostly highly correlated with each other, in that high education generally leads to an occupation with a high income. Hence, information on one of these characteristics gives valuable hints on the other two.

Even the size of the family could affect the propensity to divorce. It seems to be commonly felt that the divorce rate is higher among childless couples and families with few children, which evidently is a consequence of higher education and higher income.

The growing divorce rate is in the main a result of the effect of factors other than the changing demographic structure. As the legislation concerning marriage and divorce has remained practically unchanged, one may eliminate legislation as a factor having affected the increase in the divorce rate. Apparently the growth of divorces from the beginning of the 1960 s is almost totally the result of a changing ideology, of changes in values and attitudes, ultimately caused by the structural changes in the society.

In the following the trends and pattern of divorce in Finland will be studied by following female marriage and female age cohorts. Marriage cohorts consist of women married a certain year and age cohorts include women according to age at marriage. The marriage cohorts give an overview of changes while cohorts split up in age-atmarriage groups might reveal a more detailed picture. By studying divorce trends and patterns by cohorts, the changes in age structure could be eliminated. Finally, a short review of the divorce pattern with regard to children is made.

The effect of the changes in age structure is easily estimated. It is more difficult to get information on occupations, number of children, etc. of divorced couples, as the information provided by divorce statistics on these characteristics is either undetailed or entirely lacking.

In order to find out to what extent changes in age structure might have affected the divorce rates, the increase in divorces since 1960 is compared with the corresponding changes in the number of individuals of marital age. The comparison, which is based on the assumption that the divorce rate is the same as in 1960 , shows that only a fraction of the growth originated from changes in age structure, i.e. the increase of persons of marital age. This is the case at least in the age groups which are most exposed to the risk of divorce. From 1960 to 1970, the increase of divorces due to the augmentation of persons in marital age, primarily those at $20-29$ years of age, was only one fourth. In 1980 the corresponding proportion was only ten percent. In 1970, in the youngest age group, 15-19 years of age, the number of divorces would have been the same as in 1960. In 1980 the number of divorces was two and a half times greater. In the older age groups the changes in the divorce rate were smaller or the divorce frequency did not alter so much as in the youngest age group (Figure 2, p. 74).

\section{Divorce rates of whole marriage cohorts}

In the preceding section the divorce frequencies of the whole marriage cohort have been studied. However, the cohort consists of several age groups and the divorce pattern depends on the age of the contracting parties. A marriage between very young 
F i g u r e 2. Realgrowth of divorces from 1960 to 1970 and 1980 by age structure.

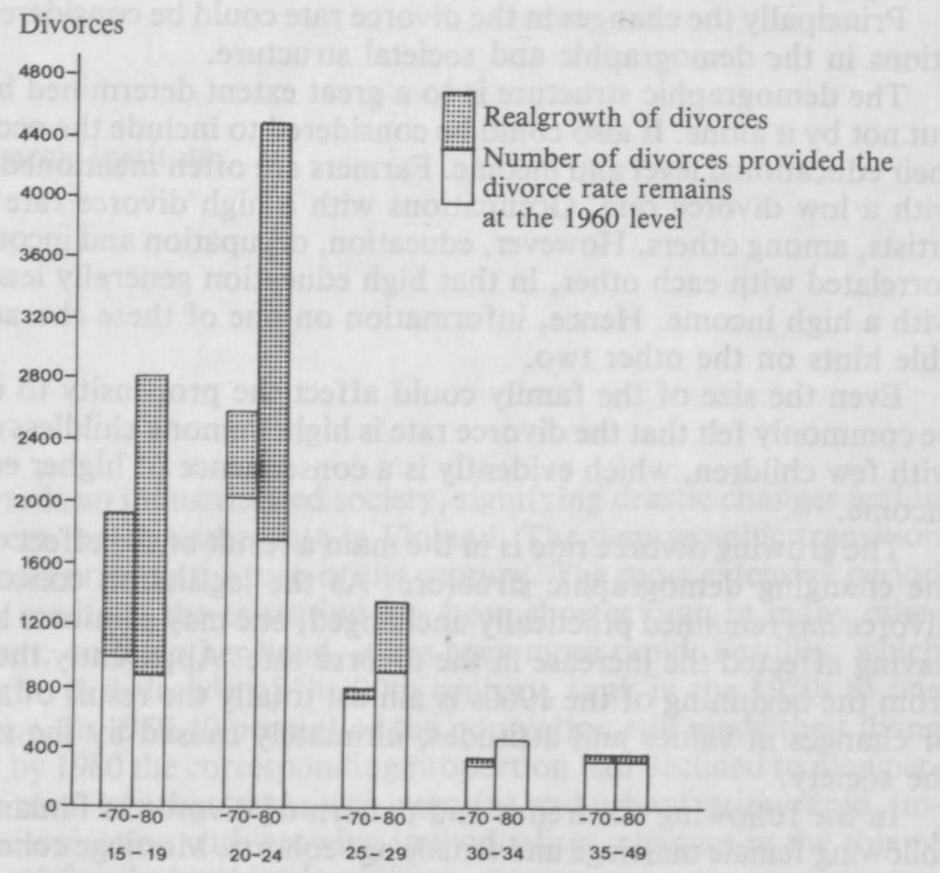

individuals could be assumed to be less lasting and more often to end in a divorce than a marriage between more mature and experienced people (Koch-Nielsen, 1983, 32). On the other hand, one might expect that individuals who have been used to living alone and making their own decisions concerning their life would have difficulties in living together and, consequently also that they would show a high divorce rate. The size and the rate of the age group affect the pattern of the whole cohort. For further analysis it is therefore important to know the size of age groups.

Characteristic of all cohorts studied is that about three-fourths or more of the marriages were contracted when the bride was under thirty years of age. The largest age-at-marriage-group was formed by those who married at 20-24 years of age. The younger and the older ones - those under 20 and those 25-29 years of age - equalled each other in size and together they totalled or sometimes were even slightly bigger than the 20-24 age group (Table 1).

$\mathrm{T} \mathrm{a} \mathrm{b} \mathrm{l} \mathrm{e} 1$. The proportion of the age-at-marriage-groups in the cohorts studied.

$\begin{array}{rrrrrrr} & 1950 & 1955 & 1960 & 1965 & 1970 & 1975 \\ -19 & 15.3 & 18.5 & 20.8 & 29.4 & 21.8 & 18.0 \\ 20-24 & 42.0 & 44.0 & 46.7 & 43.1 & 53.9 & 49.6 \\ 25-29 & 20.7 & 19.3 & 16.1 & 14.4 & 13.1 & 21.0 \\ 30-34 & 8.7 & 7.6 & 6.7 & 4.9 & 4.4 & 4.9 \\ 35-39 & 5.7 & 3.7 & 3.6 & 2.9 & 2.2 & 2.5 \\ 40-44 & 3.6 & 2.8 & 2.2 & 1.9 & 1.5 & 1.2 \\ 45- & 3.9 & 4.0 & 4.0 & 3.5 & 3.1 & 2.7 \\ & 99.9 & 99.9 & 100.1 & 100.1 & 99.9 & 99.9 \\ \mathrm{~N} & 35220 & 32640 & 32834 & 36214 & 40730 & 31547\end{array}$

Source: OSF VI A, 1950-1975 
Some changes can be noted in the proportion of the age groups during the period studied. The youngest group grew gradually to 1965 and then began to decline. The largest age group, those aged 20-24 years, seems to show a declining tendency after 1970 , while among those aged $25-29$ years at marriage the opposite development is observed, a downward movement to 1970 and after that an increase. The following rather small quinquennial age groups also show the same pattern.

During the period studied the divorce pattern of marriage cohorts has changed rather significantly. Those who married in the 1950 s show a short but rapidly increasing divorce rate ${ }^{1}$ in the beginning of the marriage which lasted four or five years. After that the rate continued more or less unchanged on the attained level (Figure 3 , p. 76). During the following years the divorce rate gradually reached a somewhat higher level. In 1960s the pattern showed signs of changing. Now the divorce rate grew higher and higher in the beginning of the marriage. After the peak had been reached, 5-8 years after the marriage had been contracted, the divorce rate began to slow down. Those married in 1970 showed twice as high a proportion of divorce five years after the wedding as the cohort married in 1960. However, contrary to the earlier pattern, the divorce rate after the peak sank rapidly to a level only somewhat higher than that of dissolutions in the 1950s. As the marriage span of the latest cohorts is rather short, it is not yet possible to know if the divorce rate of these cohorts with their »modern» pattern of divorce will stabilize on a level lower than the earlier cohorts married in the 1950 s and the 1960 s.

The increase of divorces is clearly seen in Figure 4 (p. 76), where the total proportion of divorces of the original marriage cohorts is displayed according to marriage duration. Those who married in 1950 and have been followed for more than 30 years show a total proportion of divorce of 18 percent. In the younger cohorts the same proportion was reached in an ever shortening time. Hence, the cohort married in 1970 showed the same proportion after only 13 years as the 1950 cohort had reached in 30 years.

The vertical distance between the curves gives a picture of the rapidity of the change in the divorce pattern. The greatest distance is to be found between cohorts married in 1960 and 1965, even if it is also rather distinct between those married in 1955 and 1960. The curves begin to diverge rapidly already in the beginning of the marriage, which emphasizes the increase of the divorce rate in an early stage. The difference between these curves implies that the modern pattern is emerging. The cohorts married in 1970 and 1975 seem to nearly coincide, which seems to indicate that the growth of the divorce rate has ceased and more or less stabilized on this new and higher level.

In the figures above as well as in the following figures and tables displaying marriage breakdown, only every fifth cohort has been charted. Hence the differences between the annual cohorts cannot be seen in the figures. However, it seems that the change from the old to the modern pattern has been a matter of social and ideological changes rather than merely a fashion. Consequently, it is less probable that there would be great differences between annual cohort curves.

In Figures 3 and 4, as well as in all following figures exhibiting the divorce pattern of marriage cohorts, the life table method $\mathrm{q}_{\mathrm{k}}=\mathrm{d}_{\mathrm{k}} /\left(1_{\mathrm{k}}-\mathrm{w}_{\mathrm{k}} / 2\right)$ has been used, where $q_{k}$ is the proportion of divorced couples at the end of the year, $\mathrm{d}_{\mathrm{k}}$ number of divorces in one year, $1_{\mathrm{k}}$ number of marriages in the beginning of the year and $w_{k}$ the number of marriages dissolved by the death of one of the spouses in this year (Hakulinen, 1983). The cumulative divorce rate is consequently $\mathrm{j}_{\mathrm{o}}=\mathrm{q}_{\mathrm{o}} \cdot \mathrm{q}_{1} \ldots \mathrm{q}_{\mathrm{j}-1}$.

The divorce rate is the number of divorces related to all marriages. The proportion of first marriages of all marriages varies from 88.4 percent in the cohort married in 1950 to 92.6 percent in that married in 1970. In 197590.3 percent contracted their first marriage. 
F i g u r e 3. Yearly divorce rate of some marriage cohorts from 1950 to 1975.

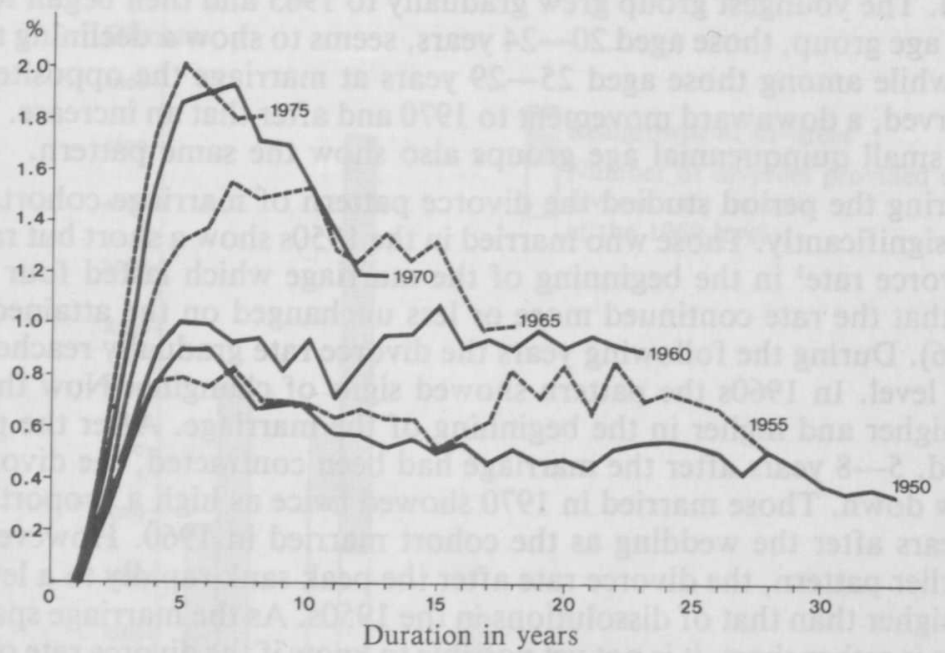

Source: OSF VI A, 1950-1982

F i g u r e 4. The cumulative divorce rate of six annual marriage cohorts from 1950 to 1975 .

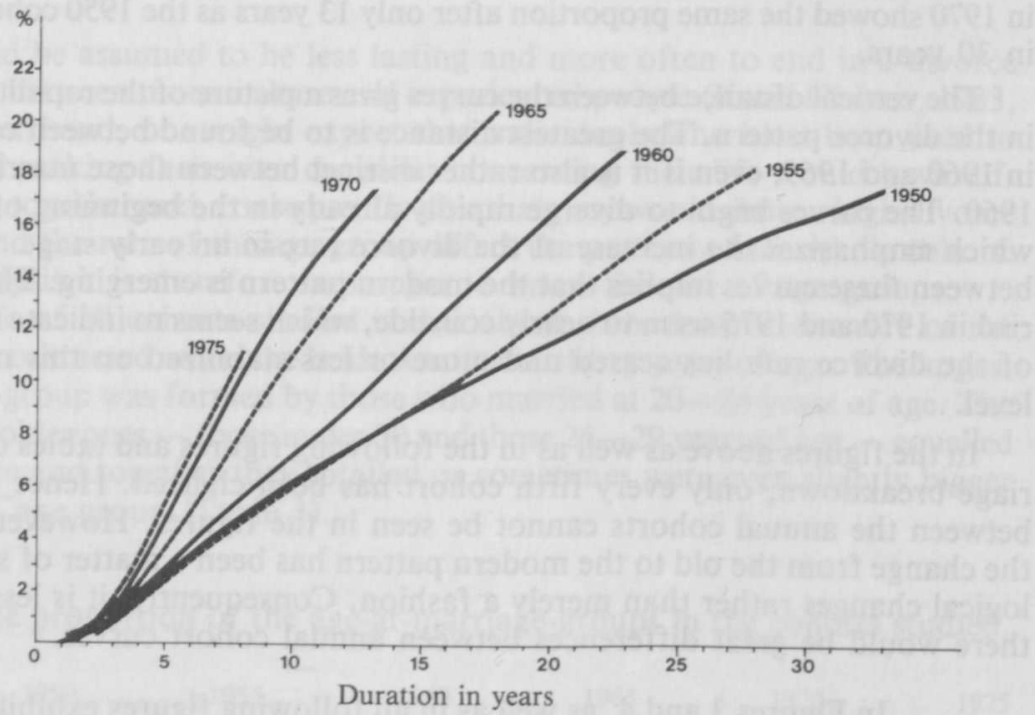

Source: OSF VI A, 1950-1982

It should be emphasized that in the model one half of the marriages dissolved by the death of one of the spouses have been excluded as censoring events from the marriages in force at the turn of the year. Thus the denominator in the model is the mean number of marriages of the year in question. This method gives a somewhat higher but obviously a more correct divorce rate than if the annual divorces had been directly related to the original marriage cohort. The 
model presumes that the divorce pattern of the couples whose marriage was dissolved by the death of one of the spouses had been the same as among those still alive. The model could be said to reflect the situation where only divorce ends the marriage.

\section{Divorce and age at marriage}

Following the same pattern as in the preceding section, we will view the annual divorce rate in different age groups of the same marriage cohorts as earlier. The age groups examined are quinquennial age groups according to the age at marriage of the bride. Omitted are those aged 45 or more. These marriages form only four percent or less of all marriages (cf. Table 1).

In conformity with the divorce pattern of the whole cohort the curves of the annual divorce rates of the earliest cohorts studied, those married in the 1950 s but also in the 1960 s, are rather flat throughout the entire marriage duration irrespective of age at marriage (Figure 5, p. 78).

In the latest cohorts, i.e. those married in the 1970s, the parabola form which is accentuated in the curves of the pattern of the whole cohort (cf. Figure 3), is clearly visible in the youngest age group, those below 20 years of age but less noticeable in the other age groups. Hence the pattern of the youngest age group strongly puts its imprint on the curve of the whole cohort.

In all cohorts more or less the same sequence prevails: the highest divorce rate is shown by those married at under 20 years of age. The difference between this age group and other older age groups is rather small in the earlier cohorts, those who follow the old pattern. The difference grows towards later cohorts with a modern pattern of divorce. In the cohort married in the 1970 s the divorce rate of the youngest age group reaches a level which is about twice as high as in older age groups. Those who married young seem to divorce more often than older couples even several years after the mode has been passed, mostly throughout the whole marriage span. The divorce rate gradually sinks to an almost non-existent level at the end of the duration studied of the oldest age groups, especially in the cohorts married in the 1950s.

As the number of marriages per age group is rather moderate, at least in the margin groups, the youngest and the two oldest ones, small changes in the number of divorces may produce great jumps. Of course, the "sawtoothing» could have been avoided if the age grouping had been based on several cohorts. Nevertheless annual cohorts or parts of it might give a satisfactory picture of the changes of the pattern of divorce.

More interesting, or at least more expressive, than the yearly divorce rates is the development of the cumulative rates. A look at the curves gives the impression of much similarity between the cohorts (Figure 6, p. 79).

The differences between the age groups, except concerning the youngest one, are rather small. In all cohorts the oldest age groups, those $40-44$ or $35-39$ years of age, display the next highest divorce rate. After 30 years $14-16$ percent of those who had contracted their marriage in 1950 had divorced, if one excludes the youngest age group where marital breakup is much higher. Those married in 1970 reached about the same level in ten years. As the divorce rate has continually increased, one may say that in the cohorts from 1950 to 1970 in all age groups excepting the youngest one the total divorce rate was roughly the same at the end of the period studied in 1982.

The exception from the rule is the youngest age group, those married at under 20 years of age. While in the two earliest cohorts all other age groups display a slightly sinking divorce tendency towards the end of the marriage duration studied, the youngest age group shows a continuous increase. Apparently the reason is that they still are "young» at the end of the period. This assumption seems to support the fact 
F i g u r e 5. The annual divorce rate according to age at marriage in marriage cohorts from 1950 to $1975^{1}$.
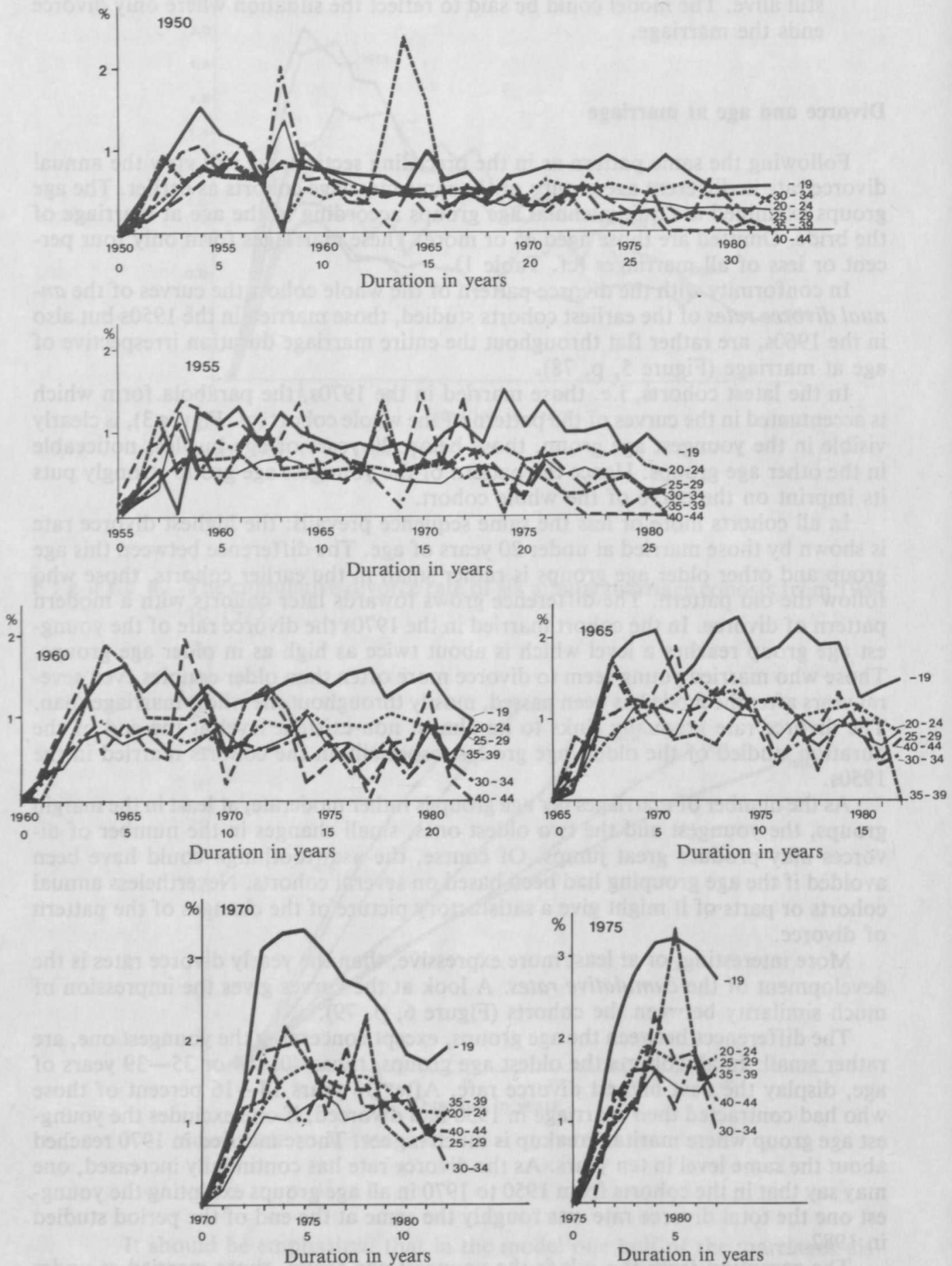

Source: OSF VI A, 1950-1982 and the Archives of the Central Statistical Office of Finland.

1 The data for the years 1950-1953 have been picked from the Archives of the Central Statistical Office of Finland. A few missing figures have been calculated by extrapolation. 
F i g u r e 6. The cumulative divorce rate according to age at marriage in marriage cohorts from 1950 to $1975^{1}$.
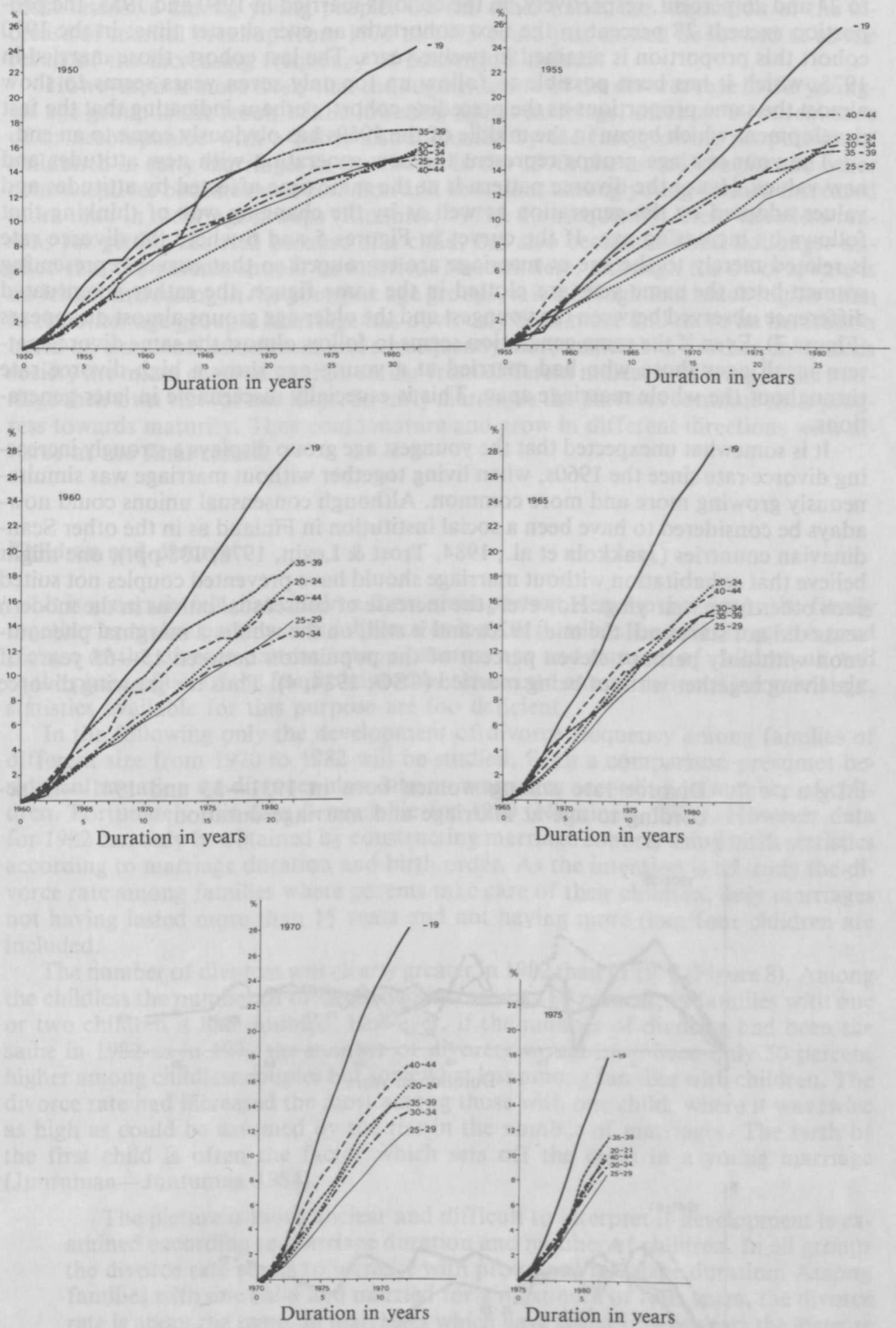

Source: OSF VI A, 1950-1982 and the Archives of the Central Statistical Office of Finland

1 See footnote in Figure 5. 
that the following older age group shows the same growing tendency even though it never reaches the same level as the youngest one. While the total divorce rate comes to 24 and 26 percent, respectively, in the cohorts married in 1950 and 1955, the proportion exceeds 28 percent in the next cohorts in an ever shorter time: in the 1970 cohort this proportion is attained in twelve years. The last cohort, those married in 1975 , which it has been possible to follow up for only seven years seems to show almost the same proportions as the preceding cohort, perhaps indicating that the fast development which began in the middle of the 1960s has obviously come to an end.

The youngest age groups represent the new generation with new attitudes and new values. Hence the divorce pattern is at the same time affected by attitudes and values adopted by the generation as well as by the changing way of thinking that follows by increasing age. If the curves in Figures 5 and 6 where the divorce rate is related merely to the age at marriage are regrouped so that curves representing women born the same year are plotted in the same figure, the rather accentuated difference observed between the youngest and the older age groups almost disappears (Figure 7). Even if the same generation seems to follow almost the same divorce pattern in all ages those who had married at a young age show a high divorce rate throughout the whole marriage span. This is especially discernable in later generations.

It is somewhat unexpected that the youngest age group displays a strongly increasing divorce rate since the 1960 s, when living together without marriage was simultaneously growing more and more common. Although consensual unions could nowadays be considered to have been a social institution in Finland as in the other Scandinavian countries (Jaakkola et al., 1984, Trost \& Levin, 1978, 138 pp.), one might believe that cohabitation without marriage should have prevented couples not suited each other from marrying. However, the increase of consensual unions in the modern sense did not start until the mid-1970s and is still, on the whole, a marginal phenomenon with only perhaps eleven percent of the population between $15-65$ years of age living together without being married (CSO, 1984, 4). Thus the growing divorce

F i g u r e 7. Divorce rate among women born in 1931-35 and 1941-45 according to age at marriage and marriage duration.
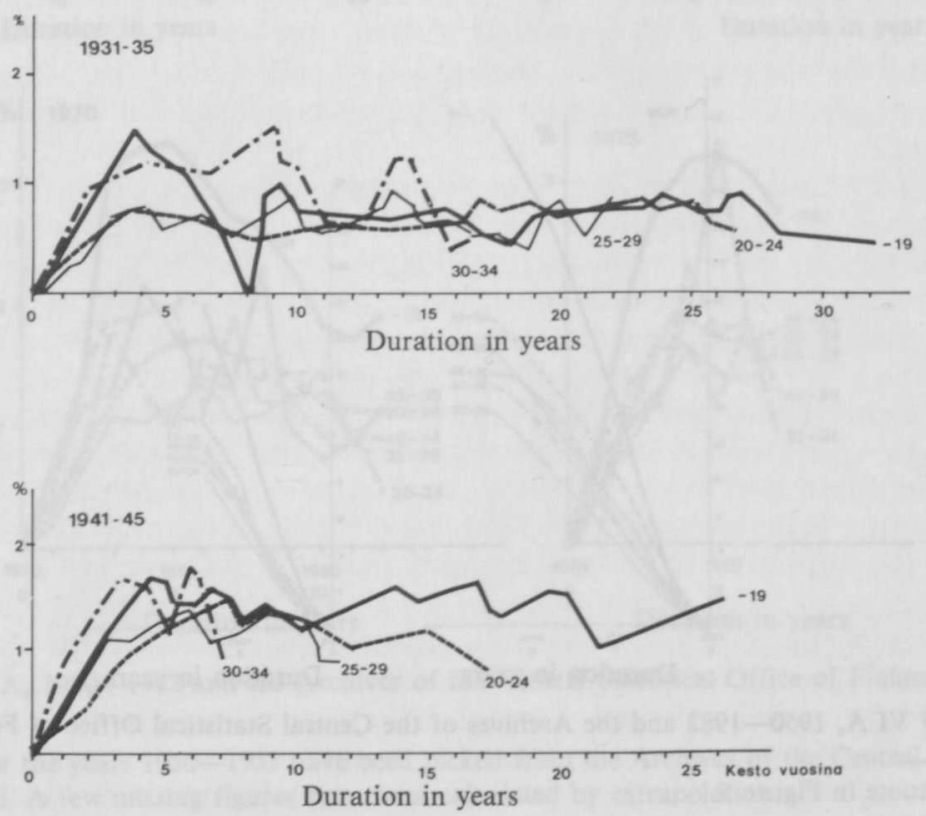
rate still found in the latter part of the marriage span among those who married under twenty years of age does not coincide with the extension of cohabitation which is most intensive among young people. On the other hand, the stagnation of the increase of marital breakup from 1970 to 1975 could just as well be looked at as the result of the increasing frequency of consensual unions.

However, it is more likely that the augmentation of the divorce rate in the youngest age group is the result of the lowering age at marriage, often as a consequence of or accompanied with a baby, also indicated by the fast growing proportion of childbirth in early marriages in the 1960s. In the 1970 s the use of the pill and other contraceptives became more common and abortions among young women increased more than in older age groups (Ritamies, 1979). Consequently, there were less reasons for getting married because of a child, but also because a child no longer implied that the parents should be married. Nevertheless, although the divorce rate is no longer increasing in the youngest age groups, it is still high and much higher than in the other age groups. Marriage has obviously been more and more an institution based on emotional attachment and consequently more vulnerable. Further, in modern society the mates come more than earlier from different milieus and bring to the marriage their own view of marriage. In early marriages the partners continue their progress towards maturity. They could mature and grow in different directions with divorce as the final result.

\section{Children and divorce}

It is generally felt that children form an important element that keeps the family together or makes parents avoid divorce as long as possible. In order to gain a good picture of the divorce pattern among parents, age and number of children as well as the phase of life of the family have to be taken into consideration. Unfortunately, statistics available for this purpose are too deficient.

In the following only the development of divorce frequency among families of different size from 1970 to 1982 will be studied. Such a comparison presumes besides information on divorces also data on marriages according to number of children. Fortunately this data is available for 1970 (Nieminen, 1972). However data for 1982 can only be obtained by constructing marriage cohorts using birth statistics according to marriage duration and birth order. As the intention is to study the divorce rate among families where parents take care of their children, only marriages not having lasted more than 15 years and not having more than four children are included.

The number of divorces was clearly greater in 1982 than in 1970 (Figure 8). Among the childless the number of divorces had incrased by 80 percent; in families with one or two children it had doubled. However, if the number of divorces had been the same in 1982 as in 1970 the number of divorces would have been only 50 percent higher among childless couples but somewhat less among families with children. The divorce rate had increased the most among those with one child, where it was twice as high as could be assumed by the rise in the number of marriages. The birth of the first child is often the factor which sets off the crisis in a young marriage (Juntumaa-Juntumaa 1984).

The picture is more unclear and difficult to interpret if development is examined according to marriage duration and number of children. In all groups the divorce rate seems to increase with prolonged marriage duration. Among families with one child and married for a maximum of four years, the divorce rate is about the same. In marriages which have lasted 10-14 years the increase is twice as large. In families with two children the tendency is the same but the growth rate smaller. Those who have three children and have been married less than ten years show an even smaller divorce rate, those married $10-14$ 
F i g u r e 8. The number of divorces among families with children 1970 and 1982.

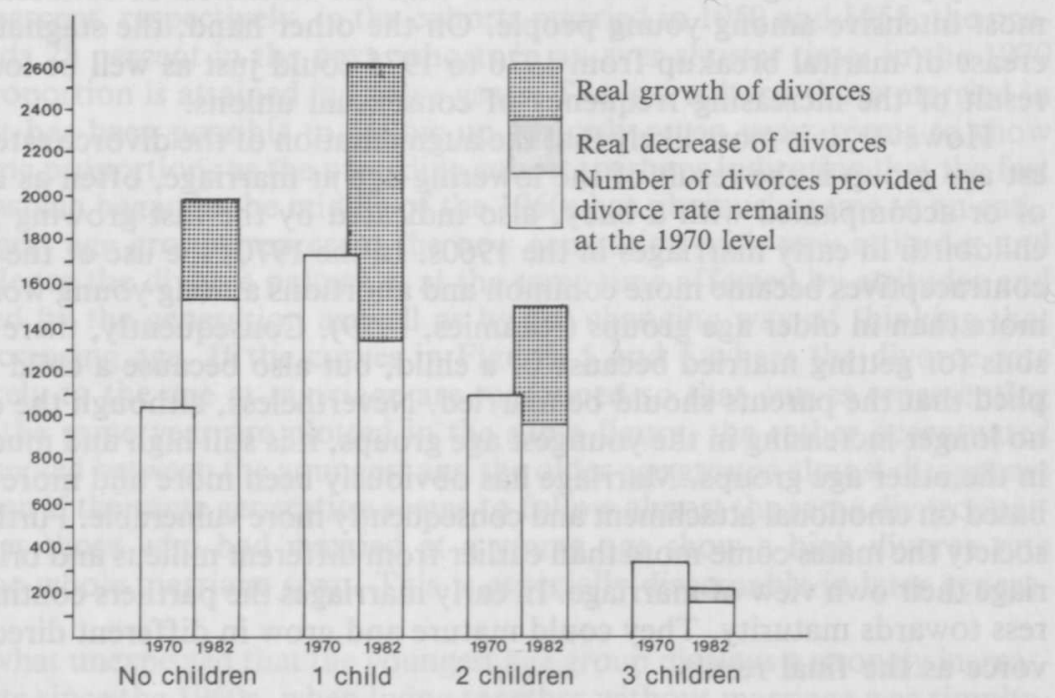

years separated in 1980 almost as often as in 1970. Among the childless the tendency is not as clear as among those with children.

The divorce rate is greatest when the marriage has lasted $10-14$ years but the increase with growing marriage duration is not as striking as among families with children.

The data revealed are based on marriages which have ended in divorce during one year. The age among those who have separated has varied and the children were born at different times of the life cycle. A more detailed examination would have demanded data on age at marriage and age at birth of children.

\section{A comparison with other countries}

A comprehensive picture of the divorce frequency in Finland presumes a comparison with neighboring countries and perhaps even with other European countries. An international comparison is often difficult, however, as the rates computed are mostly not commensurable. In the following we will only restrict ourselves to giving a rough overview of the divorce frequency in Europe.

The divorce frequency in Finland seems to be on a medium level from a European point of view, with an average of 27 divorces per 100 marriages (Table 2). Other countries with the same divorce rate are mostly countries situated in Central Europe such as Austria, Czechoslovakia and Switzerland. Among the Scandinavian countries especially Sweden, which is culturally and traditionally closest to Finland, but also Denmark are on a much higher level. Norway, on the other hand, has a rate equally as low as Finland. On the whole it seems that most countries in Europe are on this medium level. The exceptions are the two Scandinavian countries and Poland with the lowest rate in Europe. 
T a b l e 2. Divorce rate (per 100 marriages) in 1981 in some European countries.

$\begin{array}{llll}\text { Austria } & 26.6 & \text { Hungary } & 29.3 \\ \text { Belgium } & 22.6 & \text { Norway } & 27.2 \\ \text { Bulgaria } & 18.8 & \text { Netherlands } & 28.6 \\ \text { Czechoslovakia } & 26.6^{1} & \text { Poland } & 13.4 \\ \text { Denmark } & 42.5^{2} & \text { Sweden } & 43.4 \\ \text { Finland } & 27.8 & \text { Switzerland } & 27.4 \\ \text { France } & 24.7^{1} & \text { United Kingdom } & \\ \text { Germany } & & \text { England and Wales } & 38.8 \\ \quad \text { Fed. Reb. of G. } & 24.7 & \text { Scotland } & 24.4 \\ \text { German Dem. Rep. } & 32.3^{2} & \text { USSR } & 37.4 \\ 1980 & & & \\ & & & \\ & & & \end{array}$

Source: Population 1983, 4-5, p. 835

Formally the rates in Table 2 represent the divorce rate of a cohort. As the rate is the sum of the divorce rates by marriage duration in one year, it does not show the divorce frequency of a real marriage cohort married a certain year; it is composed of several marriage cohorts married in different years. Consequently this synthetic measure also reflects attitudes and customs of several generations.

\section{Some concluding remarks}

The growing divorce rate, the increase in cohabitation without marriage and the declining fertility during the last few decades are all signs of changes in attitudes and behavior concerning the family. On the whole these phenomena have followed the same pattern in Finland: the changes started approximately at the same time as in many other European countries but they have not been as highly extensive.

The main reason for this slow spread of new attitudes, especially compared with Sweden with which we always are inclined to relate the development in our country, is obviously our late departure from the old society towards industrialization, urbanization and modernization. This lag is still reflected in rather conservative and traditional thinking in spite of our willingness to adapt new ideas. The renewing of legislation has been slow and the laws concerning divorce have been practically unchanged since the end of the 1940s, although several committees have rendered their proposals for legislative reform (Committee Report, 1983, 10-11). Where legislation has been liberalized the trend towards an increasing divorce rate has accelerated (Roussel and Festy, 1979, 16).

The new attitudes and standards are initiated by the structural changes society has gone through on its way towards an industrialized society. Among the numerous changes which have transformed external circumstances special mention should be made of the new status of women. The economic emancipation of women - wellfurthered by increasing educational equality with men - has obviously contributed greatly to the growing divorce rate. In Finland the female labor force in 1982 was 62 percent of the female population aged $15-74$ years. Women are not forced to be married for economic reasons as often as was earlier the case. Women are also most frequently the driving force behind the divorce: three out of four divorces are initiated by the wife (CSO 1980, 13). Even the attitudinal tendencies in post-industrial society towards a growing individualistic and hedonistic way of thinking with selfrealization as the ultimate goal obviously contribute to making divorce a more justifiable event than earlier. On the other hand, the new subjectivism which emphasizes the importance of one's own experience and inner convinctions also stresses moral views. This contrasting feature implies possibilities for rapid changes in opinions and hence might make it difficult to predict future development. 
The development in the 1980 s as well as the latest cohorts studied give a picture of a stagnated or retarding increase. The curves of the two latest cohorts, those of 1975 and 1970, follow a very equal pattern. Has the increase definitely ceased or is this only a momentary tendency? The development in many European countries seems to point to a trend towards stagnation (Morsa, 1979, 4). On the other hand, in the neighboring country of Sweden and also in Denmark already almost one half of the marriages break up. With regard to the fact that these countries are culturally close to Finland, it is not unbelievable that the divorce frequency will still go up. Truly, the total divorce rate of the youngest cohorts will be higher than earlier ones.

\section{References}

Avioliiton solmiminen ja purkaminen (1983). Avioliittotoimikunnan mietintö. Committee report 1983: 20. Helsinki.

CSO (Central Statistical Office of Finland) (1980). Avio- ja asumuserot vuosina 1974-78. Tilastotiedotus VÄ 1980: 5. Helsinki.

CSO (Central Statistical Office of Finland) (1984). Avoliitossa elävät 1983. Tilastotiedotus VÄ 1984: 11. Helsinki.

Hakulinen, Timo (1983). Tapahtuman toteutumisen tai välttämisen yleisyyden arvioiminen. Sosiaalilääketieteellinen aikakauslehti 1983: 20. 137-147 pp.

Jaakkola, Risto et al. (1984). The diffusion of consensual unions in Finland in the 1970s. Yearbook of Population Research in Finland XXII. Helsinki. 15-25 pp.

Juntumaa, Birgitta and Juntumaa, Rauno (1984). Rakkaussuhde. Kirjayhtymä. Helsinki.

Koch-Nielsen, Inger (1983). Skilsmesser. Socialforskningsinstituttet, publikation 118. København.

Monnier, A. (1983). La conjoncture démographique: l'Europe et les pays développés d'outre-mer. Population 1983, numero $4-5,828-839$.

Morsa, Jean (1983). Family formation and dissolution: family structures. Council of Europe, European Population Conference 1982. Strasbourg.

Nieminen, Mauri (1972). Tutkimus lasten lukumäärästä. Tilastotiedotus VL 1972: 8. Central Statistical Office of Finland. Helsinki.

OSF (Official Statistics of Finland) VI A 106-148 (years 1950-1982). Population. Helsinki.

Ritamies, Marketta (1979). Fertility and legal abortions. Yearbook of Population Research in Finland XVII. Helsinki. $45-52$ pp.

Roussel, Louis; and Festy, Patrick (1979). Recent trends in attitudes and behaviour affecting the family in Council of Europe member states. Council of Europe, Population Studies no. 4. Strasbourg.

Statistical Yearbook of Finland, 1954-1984. Central Statistical Office of Finland. Helsinki.

Trost, Jan; and Levin, Bo (1978). Att sambo och gifta sig. Fakta och föreställningar. Statens offentliga utredningar 1978: 55. Stockholm. 